\title{
Isolation and screening of resistant bacteria of heavy metal (Fe) at ship dismantling
}

\author{
Harmin Sulistiyaning Titah ${ }^{1 *}$, Herman Pratikno ${ }^{2}$, Atiek Moesriati ${ }^{1}$, Rizky Islami Putera ${ }^{1}$, and Muhammad Fauzul Imron ${ }^{1}$ \\ ${ }^{1}$ Institut Teknologi Sepuluh Nopember, Department of Environmental Engineering, Faculty of Civil, Environmental and Geo \\ Engineering, Keputih, Sukolilo, 60111 Surabaya, Indonesia \\ ${ }^{2}$ Institut Teknologi Sepuluh Nopember, Department of Ocean Engineering, Faculty of Marine Technology, Keputih, Sukolilo, 60111 \\ Surabaya, Indonesia
}

\begin{abstract}
The activity of ship dismantling is one of the sources of metal pollutant that polluted the environment. The aims of this study were analyze the iron concentration from the ship dismantling area, to isolate the bacteria from those area, and to determine the bacteria resistant on iron. Samplings was conducted in three point sampling at sea water and soil coast, respectively. Isolation of bacteria was carried out using pour plate methods. All isolated bacteria in seawater and soil samples were inoculated on nutrient agar medium (NA) containing ferrous metals $\left(\mathrm{Fe}^{2+}\right)$ with various concentrations $(0 ; 1,000 ; 2,000 ; 3,000$; 4,$000 ; 5,000$; and $6,000 \mu \mathrm{g} / \mathrm{mL}$ ). Based on the results, sea water and soil indicated that those area have contaminated with iron. The concentration of iron in seawater was $1.03,1.01$ and $1.00 \mu \mathrm{g} / \mathrm{mL}$, respectively. Meanwhile, the concentration of iron in soil was $962.0,966.05,981.00 \mathrm{mg} / \mathrm{kg}$, respectively. The result of qualitative and quantitative analysis showed that the isolates of AT, AL and CL coded bacteria have high resistance to the effect of iron. It indicated with clear zone of $6.00-7.00 \mathrm{~mm}$ at $6,000 \mu \mathrm{g} / \mathrm{mL}$. In conclusion, both of bacteria are potential to be used for bioremediation of the ferrous metal $\left(\mathrm{Fe}^{2+}\right)$ in further investigation.
\end{abstract}

\section{Introduction}

The activity of ship dismantling is one of the sources of metal pollutant in coastal areas and sea water. The ship dismantling activities cause problems such as damage and pollution in coastal zones, seawater, and sediments at the demolition area. The activity mostly produces pollutants such as heavy metals or inorganic pollutan and petroleum hydrocarbons or organic pollutan that can be polluted the environment [1].

According to Yilmaz et al. [2], the types of heavy metals that be found on the shipboard dismantling area were cadmium $(\mathrm{Cd})$, chromium $(\mathrm{Cr})$, cuprum $(\mathrm{Cu})$, iron $(\mathrm{Fe})$, mangan $(\mathrm{Mn})$, nickel $(\mathrm{Ni})$, lead $(\mathrm{Pb})$, and zink $(\mathrm{Zn})$. The rank of average concentration of heavy metals that be found in the ship dismantling area was $\mathrm{Fe}>\mathrm{Zn}>\mathrm{Cu}>$ $\mathrm{Mn}>\mathrm{Cd}>\mathrm{Pb}>\mathrm{Co}>\mathrm{Ni}>\mathrm{Cr}$ [3]. The average concentration of $\mathrm{Fe}$ was the highest compared with the other heavy metals in the ship dismantling area. The average concentration of ferrous metals in the ship dismantling area was $11,932 \mu \mathrm{g} / \mathrm{g}$ to $41,361,71 \mu \mathrm{g} / \mathrm{g}$ [4]. Iron metal is one of the essential heavy metals that be needed by living organisms in certain amounts, but the excessive amounts of this metal can cause toxic effects [5].

Bioremediation of heavy metals by microorganisms is the process of transformating molecules or ions so that the toxic metal could be reduced the levels of toxicity
[6]. As the bioremediation process proceeds, the enzymes produced by microorganisms modify the toxic pollutant structure to become uncomplicated to a nontoxic and hazardous metabolite [7]. Bioremediation using microorganisms can reduce contaminants with high concentrations into harmless or le ss harmful substances. Most bioremediation processes using microorganisms are in aerobic conditions although degradation of contaminants by microorganisms may also occur under anaerobic conditions [8].

The aims of this research were to analysis the $\mathrm{Fe}$ concentration, to isolate bacteria at ship dismantling and to screen the isolated bacteria on ferrous metal $\left(\mathrm{Fe}^{2+}\right)$ for finding the high resistance capability of ferrous metal $\left(\mathrm{Fe}^{2+}\right)$.

\section{Materials and methods}

\subsection{Sampling location}

Samples of seawater and soil were collected at the coast near the ship dismantling facility in Tanjungjati, Madura, Indonesia. Seawater and soil samples were aseptically collected below surface at a depth of $20 \mathrm{~cm}$ [9] and three different randomly selected points. The distance between each sampling point was about $15 \mathrm{~m}$ (Fig. 1).

\footnotetext{
* Corresponding author: harminsulis@gmail.com
} 

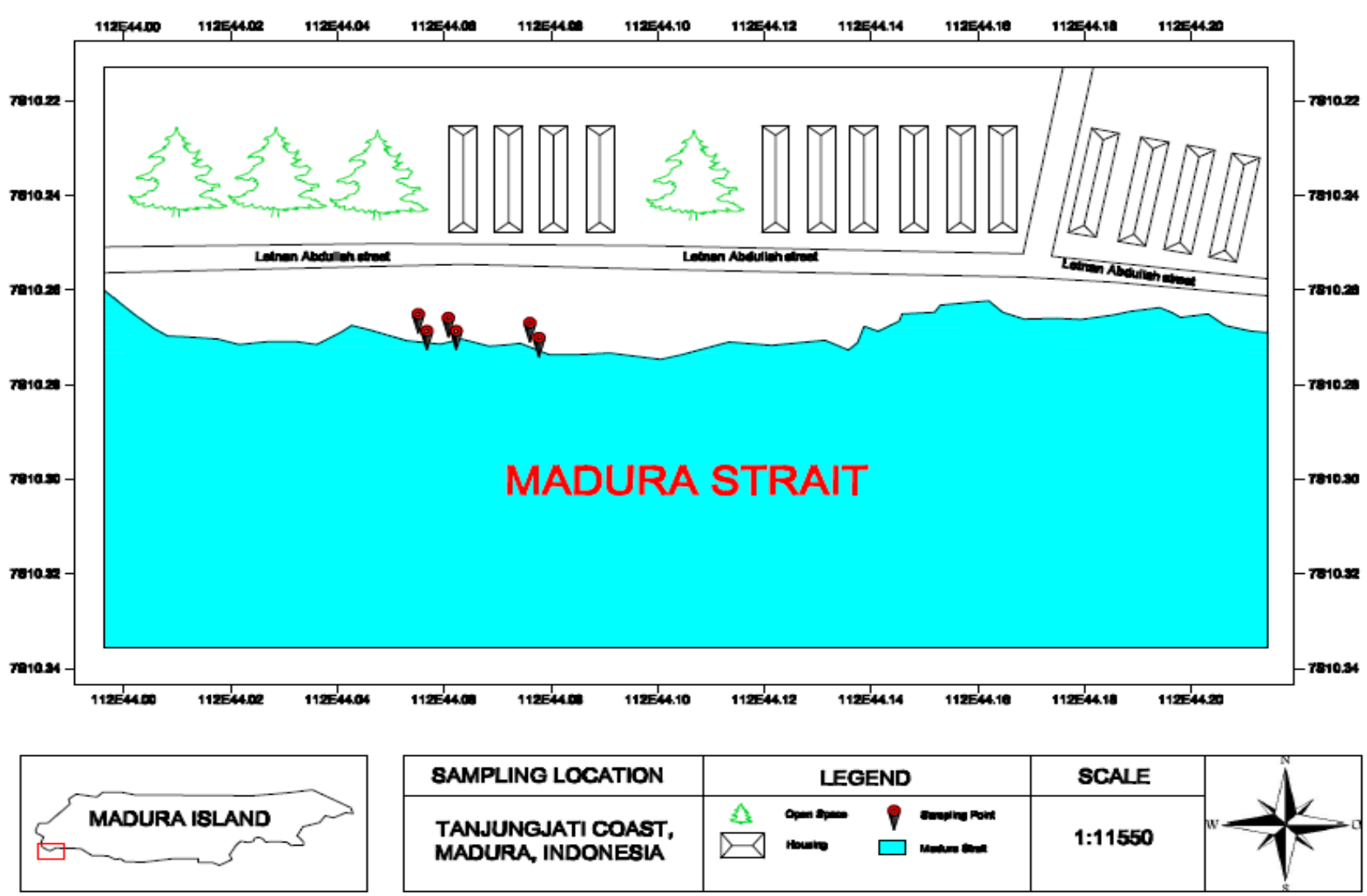

\begin{tabular}{|l|c|c|}
\hline SAMPLING LOCATION & LEGEND & SCALE \\
\hline $\begin{array}{l}\text { TANJUNGIATI COAST, } \\
\text { MADURA, INDONESIA }\end{array}$ & $\square$ 1:11550
\end{tabular}

Fig. 1. Location of sampling.

\subsection{Isolation of bacteria}

Isolation of bacteria was performed using a serial dilution method [10] and was conducted based on our previous study [11].

\subsection{Analysis of parameters}

Analysis of $\mathrm{Fe}$ concentration from seawater and soil samples were carried at laboratory. Soil extraction to determine bioavailable Fe was carried out using methods described by Quevauviller (1998) [12]. The total extractable $\mathrm{Fe}$ concentration was determined using the modified wet digestion method [13]. The concentration of Fe bioavailable and extractable were analyzed using an Atomic Absorption Spectrophotometer (AAS) instrument, Rayleigh WFX 210 (China) at Laboratory of Affiliation Team and Industry Consultation (TAKI) at Department of Chemical Engineering, ITS.

\subsection{Screening of Fe on isolated bacteria}

The screening of $\mathrm{Fe}$ on all isolated bacteria were conducted using disk diffusion method based on modified method from Jorgensen and Ferraro [14]. The stock solution of $\mathrm{Fe}$ was prepared using $\left(\mathrm{NH}_{4}\right)_{2} \mathrm{Fe}\left(\mathrm{SO}_{4}\right)_{2} \cdot 6 \mathrm{H}_{2} \mathrm{O}$ (Merck, USA). The diffusion disk method used Whatman filter paper with a diameter of 0.5 $\mathrm{cm}$ as a medium for absorbing Fe solutions. The filter paper immersed in a solution of various concentration of $\mathrm{Fe}$ and it was placed on nutrient agar (NA) (Merck,
USA). The dispersion of $\mathrm{Fe}$ can be indicated by observing the clear zone outside the filter paper, it was indicated that is not overgrown with microorganisms. The results of $\mathrm{Fe}^{2+}$ effect on bacterial growth were determined by qualitative and quantitative analysis. Clear zones can be observed at intervals of 24 hours and 48 hours after inoculation. The net zone can be obtained by measuring the radius (r) from the center point of the filter paper toward the vertical and horizontal to the 4 sides of the filter paper. Then we can calculate the average radius by using equation 1 .

$$
R=\left[\frac{\mathrm{r} 1+\mathrm{r} 2+\mathrm{r} 3+\mathrm{r} 4}{4}\right]
$$

\section{Results and discussion}

\subsection{Concentration of $\mathrm{Fe}$}

The result of measurement of $\mathrm{Fe}$ concentration at seawater and soil can be seen in Table 1. Indonesian regulation, KepMenLH No. 51 in 2004 about seawater quality standard was not mentioned the limits of Fe parameter so that it can be used or referring to government regulation in previous year if any. If there was no government regulation in the previous year, then it can refer to the regulations internationally. Some of the international standard of $\mathrm{Fe}$ concentration in seawater and soil have published. Based on international standards from Australian Water Quality Guidelines for Fresh and Marine Water Quality, it was mentioned that the standard of Fe concentration in water is $<0.3 \mathrm{mg} / \mathrm{L}$ (300

\footnotetext{
*Corresponding author: $\underline{\text { harminsulis@gmail.com }}$
} 
$\mu \mathrm{g} / \mathrm{L})$, sea water at $\mathrm{pH}>6$, and then $\mathrm{Fe}<1 \mathrm{mg} / \mathrm{L}(1000$ $\mu \mathrm{g} / \mathrm{L})$, whereas at $\mathrm{pH}<6$ then $\mathrm{Fe}<0.3 \mathrm{mg} / \mathrm{L}(300 \mu \mathrm{g} /$ L) $[15]$.

Table 1. Summary of Fe Concentration in sample.

\begin{tabular}{|c|c|c|c|c|}
\hline \multirow{2}{*}{ Sampel } & Haevy Metal & \multicolumn{3}{|c|}{ Concentration of Fe } \\
\cline { 3 - 5 } & & $\mathbf{1}$ & $\mathbf{2}$ & $\mathbf{3}$ \\
\hline $\begin{array}{c}\text { Seawater } \\
(\mathrm{mg} / \mathrm{L})\end{array}$ & Total Fe & 1.03 & 1.01 & 1.00 \\
\hline $\begin{array}{c}\text { Soil Coast } \\
(\mathrm{mg} / \mathrm{kg})\end{array}$ & $\begin{array}{c}\text { Bioavailable } \\
\text { Fe }\end{array}$ & 270.4 & 200.5 & 165.5 \\
\cline { 2 - 5 } & Extractable Fe & 962 & 967 & 981 \\
\hline
\end{tabular}

The international standards for $\mathrm{Fe}$ concentration in sediments refered to the Compilation of Sediment and Soil Standards, Criteria and Guidelines, California in 1995 [16]. Based on those standard, Fe contaminated areas on sedimentary media was classified become 3 categories, i.e. not polluted if the concentration of $\mathrm{Fe}$ $<17 \mathrm{mg} / \mathrm{kg}$, moderately polluted if Fe between $17-25$ $\mathrm{mg} / \mathrm{kg}$ and when the concentration of $\mathrm{Fe}>25 \mathrm{mg} / \mathrm{kg}$. Tabel 2 showed some standard of $\mathrm{Fe}$ at seawater and marine sediment.

Table 2. Some Standard fo Fe Concentration.

\begin{tabular}{|c|c|c|}
\hline \multirow[b]{2}{*}{ Guidlines } & \multicolumn{2}{|c|}{ Concentration of $\mathrm{Fe}$} \\
\hline & $\begin{array}{c}\text { Seawater } \\
(\mathrm{mg} / \mathrm{L})\end{array}$ & $\begin{array}{c}\text { Soil Coast/sediment } \\
(\mathrm{mg} / \mathrm{kg})\end{array}$ \\
\hline USEPA (2002) & 0.3 & $17-25^{*}$ \\
\hline WPCL (2004) & 0.3 & - \\
\hline CIW (1997) & 5 & - \\
\hline $\begin{array}{l}\text { TSE - 266 } \\
(2005)\end{array}$ & 0.2 & - \\
\hline EC (1998) & 0.2 & - \\
\hline
\end{tabular}

Source : Ozturk et al. [17], USEPA [18]*

Based on Table 1, the concentration of Fe in sea water was $1 \mathrm{mg} / \mathrm{L}$ and the concentration of Fe in soil was $>200 \mathrm{mg} / \mathrm{kg}$. Based on USEPA [18] (Table 2), the standard of $\mathrm{Fe}$ in seawater was $0.3 \mathrm{mg} / \mathrm{L}$ and in the soil was $17-25 \mathrm{mg} / \mathrm{kg}$. Meanwhile, based on the Ministry of Environment in 1988 states the quality standard of Fe in seawater $<1 \mathrm{mg} / \mathrm{L}$. Based on the above quality standards, the seawater and soil at the area of ship dismantling at sampling location was contaminated by Fe.

\subsection{Isolated bacteria}

Based on our previous study [11, 19], total colony number at soil coastal and seawater samples were $6.3 \times 10^{8} \mathrm{CFU} / \mathrm{mL}$ and $1.47 \times 10^{9} \mathrm{CFU} / \mathrm{mL}$, it indicated that many colonies of bacteria could grow from sample at contaminated locations. After preliminary observation on colonies using microscope with magnification of $40 X$, i.e. 7 colonies of bacteria from sea water samples and 8 colonies of bacteria from soil coastal samples.

\subsection{Screening of $\mathrm{Fe}$ on isolated bacteria}

Although fifteen strains bacteria can be isolated, but thirteen isolated bacteria were used in screening test due to 2 strains have same morfology with others. Thirteen single isolated bacteria were inoculated on each nutrient agar medium (NA) containing $\mathrm{Fe}^{2+}$ with various concentrations $(0 ; 1,000 ; 2,000 ; 3,000 ; 4,000 ; 5,000$ and $6,000 \mu \mathrm{g} / \mathrm{mL})$. The calculation results of the average clear zone radius of bacterial growth after 24 hours was shown in Table 3.

The clear zone was formed on high of $\mathrm{Fe}$ concentration. The greater of clear zone indicated that bacterial growth was lower. High concentrations of heavy metals inhibited bacterial growth, altered morphology, and disturbed the metabolism of organisms invitro manner [20].

Based on Table 3, it showed that the isolates of AT, $\mathrm{AL}$ and $\mathrm{CL}$ coded bacteria have high resistance on $\mathrm{Fe}^{2+}$. Three of coded bacteria showed diameter clear zone was smaller than in other coded bacteria at the high $\mathrm{Fe}$ concentrations of $6,000 \mu \mathrm{g} / \mathrm{mL}$. The others coded bacteria also showed growth at high concentrations of Fe but not reach as high as the concentration $\mathrm{Fe}$ of 6,000 $\mu \mathrm{g} / \mathrm{mL}$. However, overall the thirtheen strains bacteria have a good ability on Fe precense due to it suggested that all the bacteria were isolated from Fe contaminated area. Physiological ability of bacteria to overcome the environmental stress of contaminated heavy metals depends on bacterial metabolism. Bacterial resistance and adaptation to heavy metals depends on the species and concentrations of heavy metals exposed around the bacteria [21]. The binding of heavy metals by bacteria can be separated into active binding and transport phases. The binding phase depends on cell metabolism ie absorption through cell wall or external surface, followed by active transport dependent on cell metabolism. In metabolic processes, heavy metals can accumulate in cell membranes (extracellular) and in the cytoplasm (intracellular).

Table 3. Summary of screening test.

\begin{tabular}{|c|c|c|c|c|c|c|c|}
\hline \multirow{2}{*}{$\begin{array}{c}\text { Bacterial } \\
\text { Code }\end{array}$} & \multicolumn{7}{|c|}{ Concentration of $\mathrm{Fe}^{2+}(\mu \mathrm{g} / \mathrm{mL})$} \\
\hline & 0 & 1,000 & 2,000 & 3,000 & 4,000 & 5,000 & 6,000 \\
\hline \multicolumn{8}{|c|}{ Seawater } \\
\hline $\mathrm{AL}$ & ++++ & ++++ & ++++ & +++ & ++ & ++ & + \\
\hline $\mathrm{BL}$ & ++++ & +H+ & ++ & + & + & - & - \\
\hline $\mathrm{CL}$ & ++++ & +H+ & +++ & +++ & ++ & + & + \\
\hline DL-1 & ++++ & ++++ & +++ & + & - & - & - \\
\hline EL & ++++ & H+t & ++ & ++ & + & + & - \\
\hline FL & ++++ & +++ & ++ & - & - & - & - \\
\hline \multicolumn{8}{|c|}{ Soil Coast } \\
\hline AT & ++++ & ++++ & +++ & +++ & ++ & + & + \\
\hline BT & ++++ & ++++ & ++ & ++ & + & - & - \\
\hline CT & +++++ & ++++ & +++ & ++ & ++ & + & - \\
\hline ET & +++++ & ++++ & ++ & - & - & - & - \\
\hline FT & +++++ & ++++ & +++ & ++ & + & - & - \\
\hline GT & +++++ & ++++ & +++ & +++ & ++ & + & - \\
\hline HT & +++++ & +H+ & +++ & +++ & + & + & - \\
\hline
\end{tabular}




\section{Explanation :}

+++++ : Avg. of radius of clear zone $<3,00 \mathrm{~mm}$

++++ : Avg. of radius of clear zone $3,00 \mathrm{~mm}-4,00 \mathrm{~mm}$

++ : Avg. of radius of clear zone $4,00 \mathrm{~mm}-5,00 \mathrm{~mm}$

$+\quad$ : Avg. of radius of clear zone $5,00 \mathrm{~mm}-6,00 \mathrm{~mm}$

$+\quad$ : Avg. of radius of clear zone $6,00 \mathrm{~mm}-7,00 \mathrm{~mm}$

- $\quad$ : Avg. of radius of clear zone $>7,00 \mathrm{~mm}$

\section{Conclusion}

The concentration of Fe in seawater was 1.03, 1.01 and $1.00 \mu \mathrm{g} / \mathrm{mL}$, respectively. Meanwhile, the concentration of extractable $\mathrm{Fe}$ in soil was 962.0, 966.05, 981.00 $\mathrm{mg} / \mathrm{kg}$, respectively. It indicated that location sampling was contaminated with Fe. The result of qualitative and quantitative analysis of $\mathrm{Fe}$ screening showed that the isolates of $\mathrm{AT}, \mathrm{AL}$ and $\mathrm{CL}$ coded bacteria have high resistance to the effect of iron. In conclusion, those bacteria were potential to be used for bioremediation of the ferrous metal $\left(\mathrm{Fe}^{2+}\right)$ in further investigation.

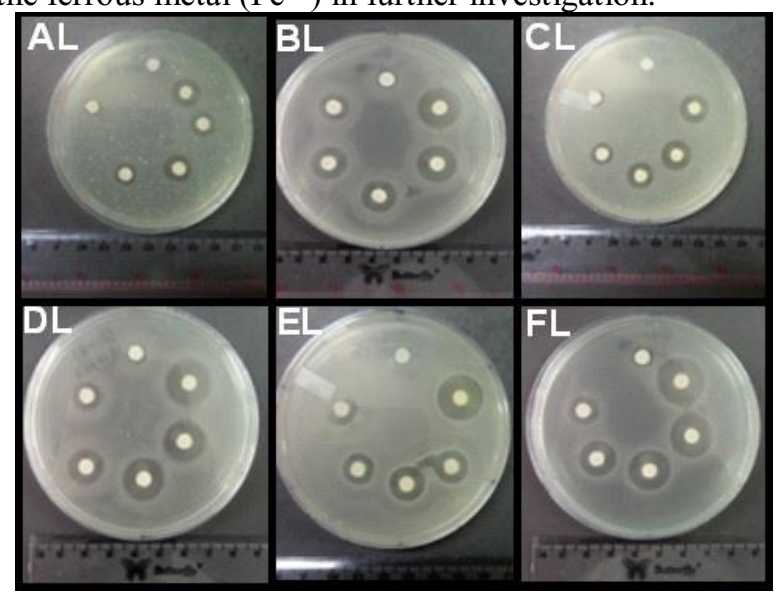

Fig. 2. Screening of isolated seawater bacteria on NA media with $\mathrm{Fe}$.

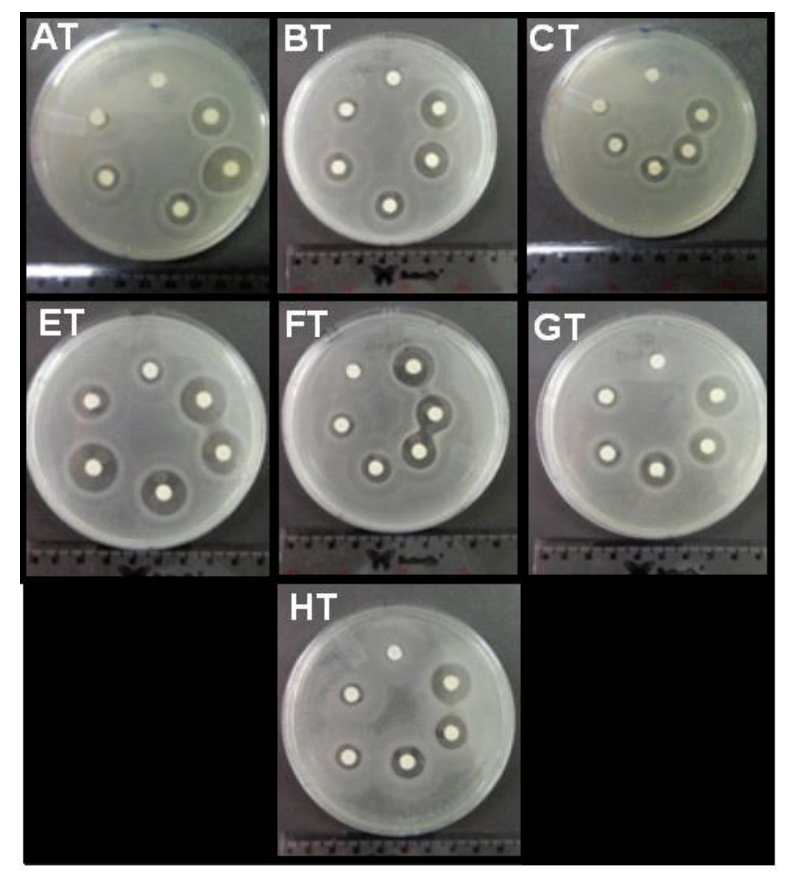

Fig. 3. Screening of isolated soil bacteria on NA media with Fe.
The author would like to thank KemenristekDIKTI through scheme of Penelitian Terapan Unggulan Perguruan Tinggi PDUPT 2018 No. 1021/PKS/ITS/2018 for funding this research.

\section{References}

1. A. Kacar, A. Kocyigit, A. Int. Journal of Environ. Res. 7(4)895-902 (2013)

2. A. Yilmaz, B. Karacik, S. Yakan, D. Henkelmann, W. Schramm, O.S. Okay. Ocean Eng. 123,452-457 (2016).

3. S. Basha, P.M. Gaur, R.B.Thorat, R.H. Trivedi, S.K. Mukhopadhyay, N. Anand, S.H. Desai, K.H. Mody, B. Jha. Water Air Soil Pollut 178:373-384 (2007).

4. N.A. Siddiquee, S. Parween, M.M.A. Quddus, P. Barua. Heavy metal pollution in sediments at Ship Breaking Area of Bangladesh. Environand Poll 3 712 (2009)

5. Ika, Tahril, I. Said. J. Akad. Kim. 1(4) 181-186. (2012)

6. M. Yazid. Kajian Pemanfaatan Bakteri hasillsolasi sebagai Agen Bioremediasi Radionuklida Uranium di Lingkungan. Pusat Teknologi Akselerator dan Proses Bahan (BATAN, Yogyakarta 2007).

7. S.K Chandrakant, S.R. Shwetha, S. Rao. Enzyme Research 1-11 (2011)

8. P. Sivaperumal, K. Kamala, R. Rajaram, R. Advances in Food and Nutrition Res. 80 165-179 (2016)

9. S.K. Bhasheer, S. Umavathi, D. Banupriya, M. Thangavel, Y. Thangam, Y. Int.J.Curr.Microbiol.App.Sci, 3(11), pp. 363-369, 2014.

10. J.P. Harley, L.M. Prescott. Laboratory exercises in microbiology. Fifth Edition. (McGraw-Hill Companies, Texas, 2002)

11. H.S. Titah, P. Herman, A. Moesriati, R.I. Putera, M.F. Imron. Journal of Engineering and Technological Sciences 50(1) 99-109 (2018)

12. Ph., Quevauviller. Methodologies in Soil and Sediment Fractionation Studies, Single and Sequential Extraction Procedures. (Royal Society of Chemistry, UK, 1998)

13. H.S. Titah, S.R.S. Abdullah, M. Idris, N. Anuar, H. Basri, M. Mukhlisin. Ecological Engineering. 58 303-313 (2013)

14. J. Jorgensen, M. J. Ferraro. Medical MicrobioL. 2009(49), 1749- 1755 (2009)

15. Anzecc, Armcanz.. Australian Water Quality Guidelines for Fresh and Marine Water Quality (2000)

16. Quality Assurance Technical Document 7. Compilation of Sediment \& Soil Standards, Criteria \& Guidelines. Department of Water Resources Quality Assurance/Quality Control Program, State of California (1995)

17. M.G. Öztürk, O. Özözen, E. Minareci, Minareci.. Determination of Heavy Metals in Fish, Water and 
Sediments of Avsar Dam Lake in Turkey. Iran. J. Environ. Health. Sci. Eng. 6(2) 73-80 (2009)

18. EPA. 2002. Arsenik treatment technology for soil, waste dan water. (www.epa.gov/tiocluin.org/arsenic).

19. H.S. Titah, P. Herman, A. Moesriati, R.I. Putera, M.F. Imron. Proceedings of International Conference : Problem, Solution and Development and Delta Area, ICCDA\#3 (2017)

20. D. Blaudez, B. Botton, M. Chalot, M.. FEMS Microbiol. Ecol 33, 61-67 (2000).

21. Y.A. Prasetya, N.D. Kuswytasari, E. Zulaika. Adaptasi Genera Bacillus pada Media yang Mengandung Logam Timbal. Scientific Conference of Enviromental Technology IX-2012 2(2012) 